\title{
ENTREVISTA COM NELSON LEIRNER
}

\author{
por RAFAEL VOGT MAIA ROSA
}

Nelson Leirner é um desses artistas cuja biografia se confunde com lendas pessoais. Como se sabe, isso acaba, em muitos casos, por constituir mais uma estratégia poética, um contexto inescapável que se sobrepõe à criação de trabalhos diversos, mas que se mostram coesos. Sua prolongada atuação como professor, seus happenings e depoimentos, tudo parece colaborar para um percurso extraordinário de realizações que permanecem na órbita de um questionamento não apenas formal do fazer artístico, mas, de uma

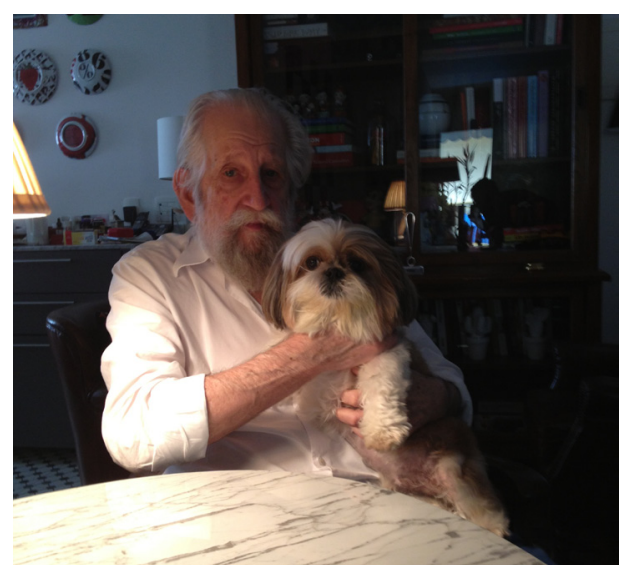
polêmica em curso. Entretanto, diferentemente do caráter mítico e iniciático do famoso, historicamente improvável, acidente aéreo de Joseph Beuys, no caso de Leirner, sua entrada nas artes plásticas brasileiras é desmistificada pelo próprio artista.

Um pouco ao modo de Oswald de Andrade, que escreve em 1933 um antiprefácio para seu romance-invenção Serafim Ponte Grande - provavelmente a obra mais iconoclasta de nosso modernismo -, em que revê seu percurso artístico sem quaisquer pudores, Nelson Leirner também se coloca em xeque sistematicamente, evocando, de forma indireta, a despeito de um engajamento e das contradições, a figura de um "palhaço da burguesia" que se percebeu envergonhado nessa condição.

$\mathrm{Na}$ entrevista a seguir, Leirner fala, entre outras, justamente de sua iniciação "às avessas", ou, simplesmente avessa à pintura tradicional - elemento que ressoa em diversas exposições suas -, da inserção e valorização de sua obra no mercado, de ansiedade e envelhecimento. Algumas passagens são conhecidas do público por revisões pioneiras de sua obra - como O Fim da Arte Segundo Nelson Leirner, publicada em 1994, por Agnaldo Farias, e Nelson Leirner: Arte e Não Arte (2002), de Tadeu Chiarelli. Não deixa de surpreender ainda que não percam uma função pseudo-didática ao reiterarem escrupulosamente uma obviedade que resvala no absurdo - quase como um crime solucionado ao contrário, da confissão à falta de provas materiais. 
Com 81 anos - radicado no Rio de Janeiro há 18 - Leirner se diz um "cínico" em sentido amplo e, ao mesmo tempo, com toda a sua experiência, surpreso com um processo de embelezamento geral da arte produzida hoje e com a arrogância de "jovens" artistas e curadores.

Em outra ocasião, tentei entrevistá-lo e você sugeriu que as perguntas feitas demandavam uma resposta pessoal minha na forma de um ensaio. E, levantou essa questão a partir de outros depoimentos seus anteriores e da 'repetição' de ideias associadas ao seu trabalho. Pois eu queria tentar partir daí: em seu percurso, será que repetir não é um modo de superar uma premissa de progresso e mesmo da construção de uma carreira?

Nelson Leirner - "tornar a dizer... repisar... acontecer de novo..." fazer o mesmo trabalho não em forma de multiplicação ou série mas sim conceitualmente, o que não é a mesma coisa que criar uma assinatura, ter o seu perfil reconhecido, metaforicamente como numa série de televisão que estou vendo, Criminal Minds, na qual os assassinos são pegos por uma análise comportamental, o mesmo que os artista que eu denominaria como os serial killers da arte.

\section{Como a ansiedade entra no seu trabalho?}

Leirner - A ansiedade é com a vida, não é com a arte. A gente tem uma ansiedade vivencial. O tempo vai passando, a gente vai querendo ficar sozinho, mais afastado de tudo. Ao mesmo tempo você tem que lidar com um mundo da arte que é irritante. Então eu acho que a ansiedade está ligada a essa conexão de você, com o tempo, querer se afastar de tudo, você ficar muito mais neurótico, introspectivo... Você fica muito mais querendo ficar na sua, como se dissesse: "você não faz mais as coisas com prazer..." Elas começam a te irritar. O dia a dia, a arte.

\section{E sem a arte a vida seguiria que rumo?}

Leirner - Ontem meu irmão veio aqui e eu conversei muito com ele sobre isso. Porque ele teve que largar a medicina, porque ele fazia uma medicina não de consultório, que não tem idade para terminar. E meu irmão trabalhava no INCOR, ele era diretor da bioengenharia. Quando você trabalha num órgão público, você tem uma idade para se aposentar. Você tem que cortar. Dentro da sua área, tem que sair fora. Não tem mais o seu trabalho, dentro da área. Então você tem que criar algo novo que substitua o que está fazendo. Ele, por exemplo, começou a fotografar. Começando a fotografar, ele já começa a entrar nesse universo da galeria, de tudo..., já começa a ter idade e ver as dificuldades. Mas ele 
conseguiu sair de uma para se recolocar. Agora, eu falo para ele, mas se eu parar, dentro da arte, que é uma puta vontade que eu tenho, eu não posso ser médico. Entende?

Quer dizer, ele é seu irmão, mas tem um percurso bem diferente.

Leirner - Lógico. Então eu preciso encontrar um hobby que me substitua a arte. Porque também ficar parado não dá.

E você tem alguma coisa em vista, algo que cultivou em paralelo?

Leirner -Não. Nada. Porque meu hobby sempre foi cultivar a arte dentro do processo do próprio hobby.

Você deu um depoimento sobre o Geraldo de Barros, em um documentário de Michel Favre, dizendo que admirava nele a capacidade de parar, de fazer outras coisas...

Leirner - É..., mas ele criou uma indústria. Ele largou de ser artista e virou industrial. E voltou a fazer arte só depois que teve o derrame. Porque aí ele não tinha mais como ser industrial, como ser diretor da Hobjeto. Aí ele pegava e mandava fazer em fórmica - nem ele fazia -, como ele tinha a Hobjeto, ele desenhava as fórmicas. E ele teve que voltar a ser construtivista, geométrico em função da comunicação dele com quem ia executar. Porque ele não podia pintar, ele não podia fazer nada. Mas podia dizer, "põe um vermelho aqui, põe um amarelo aqui", vamos dizer, ele podia mondrianar, todos os seus trabalhos verbalmente. Ele não podia mais ser gestual, não podia mais mudar. Então ele voltou à época em que ele era geométrico. Agora, é tudo por circunstâncias.

Eu te perguntei muito genericamente sobre a questão literária no seu trabalho. Em 1980 você fez uma exposição que tinha um texto seu, de apresentação, Pague pra ver. A exposição foi "embargada”. Ou seja, a exposição não aconteceu, mas o texto ficou.

Leirner - O texto ficou uma espécie de manifesto, vamos supor. Na galeria Múltipla, que era da mulher do Vlavianos - uma ótima pessoa. Eu fiz o convite, que eram aquelas cinco cartas do baralho, uma escondida.

\section{Um royal straight flush?}

Leirner - Seria um royal straight flush e atrás eu escrevi esse pequeno manifesto, meu, sobre arte comercial. Como se deve fazer arte... 


\section{Comercial}

Leirner - Comercial: você faz isso, a pintura vale mais que...

É..., você fala das diferenças entre as mídias, que você gostaria de agregar o valor usando todas, das dimensões dos trabalhos, preço, estética, do próprio marchand e da crítica. $O$ início é assim, quer ver?: "Consegui. Vinte anos de tentativas para finalmente chegar aonde queria: VENDA GARANTIDA, ARTE COMPROMISSADA, ARTE COMERCIAL PURA."

Leirner - Quando ela leu esse texto, viu que ia contra o estatuto da galeria. Era um texto crítico a todo o sistema de arte.

De qualquer modo, você tinha trabalhos que poderiam ter sido expostos.

Leirner - Sim, qualquer trabalho poderia ser exposto.

Mas não eram trabalhos em que você justamente se utilizou de várias mídias?

Leirner - Era toda uma série erótica.

E você acha que ela pode ter estranhado porque era uma série erótica?

Leirner - Não. Porque ela tinha uma galeria onde se propunha a expor o que você quisesse expor lá. Era o texto do convite. Ela disse que eu estava atacando a galeria dela pelo convite. E os compradores, a sociedade, digamos.

E isso não implica que uma parte do seu trabalho que aconteceu pela escrita traz uma perspectiva em que não se realiza visual ou mesmo materialmente?

Leirner - São o que eu chamo de happenings. Isso é um happening, praticamente, porque a galerista cancela a exposição. Ela cancelou a exposição porque não quis distribuir o convite. Ela me disse: "faça outro texto que a gente faz a exposição".

E você não fez.

Leirner - Aí eu não faço, claro. Então você cria o mecanismo para que a sociedade, se ela não aceitar, já tomou uma posição e não pode voltar atrás.

No resumo biográfico do seu site, está escrito que “em 1956, teve aulas de pintura com Juan Ponç, abandonando-as para buscar outras formas 
estimulantes para seu trabalho além de pintura sobre tela." Como foi essa sua iniciação à pintura?

Leirner - O Ponç era meu amigo. Ele veio de Barcelona, toda aquela zona, na Espanha, reconhecido por lá. A gente saía muito e almoçava toda semana juntos num chinês, batia papo. E ele chegou para mim e disse, "Nelson, você não quer começar a pintar?" Porque ele pintava, mas não mostrava o que fazia. Ele era meio...

\section{Paranóico?}

Leirner - É. Ninguém via os trabalhos que ele fazia. Depois se veio a ver, em uma Bienal ou coisa assim. Mas naquela época, em 1956, eu tinha um espaço, uma casa velha do meu pai na rua Veiga Filho... que estava abandonada. Falei, vamos começar. Minha mãe já era artista eu já tinha contato com pessoal de Bienal. Eu já estava um pouco no meio da arte, sem entrar nela. E começamos a pintar. Só que a pintura, primeiro, era uma pintura a óleo - não havia acrílico na época. Você começava com três, quatro trabalhos ao mesmo tempo. Um quadrinho, um quadrinho, um quadrinho, um quadrinho... E ele te ensinava veladuras... coisas, aquele negócio que você colocava para pôr a mão e dar firmeza... pra fazer o traço. E eu comecei a ver que o processo da pintura para minha cabeça era muito lento. Sabe? Ter que esperar 15 dias para um quadro secar para depois retomar... E com o óleo você não pode... Porque se você coloca outra cor por cima do óleo sem estar seco, ela mistura. E eu estava aprendendo a fazer as coisas planas... E eu comecei a ficar um pouco irritado com esse processo lento da pintura.

\section{Não dava prazer.}

Leirner - Não. Me irritava, era muito lento. E eu já tinha uma certa ansiedade...

\section{Ansiedade?}

Leirner - Sim. Essa ansiedade que hoje a gente não tem, aquilo, sim, tinha uma ansiedade de fazer, de criar, de ver. Passou um ano e eu falei, "Ponç, eu não vou mais querer aula, eu não aguento mais". Aí ele ficou ofendido e brigou comigo. E então eu passei seis meses sem fazer nada, quase seis meses ou um ano. Zero.

\section{O que seria esse "fazer nada"?}

Leirner - Nada no campo da arte. Trabalhava com meu pai na fábrica dele e tal. Então, quem frequentava muito a casa dos meus pais era o Flexor com a sua mulher, a Margot, pois eles eram muito amigos. E o Flexor tinha um ateliê 
de pintura onde ele dava aulas. Dava aulas para o Leopoldo Raimo, Douchez, Norberto Nicola... era todo um pessoal. E todos sabiam que eu tinha começado a pintar, e ele me convidou, "venha assistir umas aulas minhas, passa lá, pega uma tela" - de novo, tela e pintura. E eu quando entrei naquela sala, comecei a fazer, porque ele mandava primeiro fazer o desenho do que eu queria...

\section{Diferente do Ponç}

Leirner - Sim, porque ele era abstrato. Era um abstracionismo que não chegava ao geométrico, mas também era uma pintura lisa. E eu ficava vendo todos os alunos dele. E o Flexor era aquele tipo de professor que ensinava a ser Flexor. Então todos os alunos eram pequenos "flexors"... Durou três meses e eu disse, "Flexor, me desculpe, eu não consigo". Mas não foi nem aula, foram três meses de experiência no ateliê dele

\section{E ele também se ofendeu?}

Leirner - Não, ele entendeu porque eu fui lá como aluno. Fui lá para ver se eu recomeçava.

Tinha essa ideia de que o pai quer endireitar a vida do filho e arruma um trabalho para ele?

Leirner - Tem. Eles forçam a barra. Meu pai era diretor do MASP, diretor da Bienal, minha mãe escultora... eles me forçaram na arte.

\section{E seu pai chegou a entender, admirar o que você fazia?}

Leirner - Ele me forçou ser artista. Ele viu que eu, como industrial, não dava, realmente eu não tinha o menor interesse e forçou a barra.

Mas quando você se tornou artista, se é que se pode falar assim, qual era o entendimento dele em relação ao que fazia?

Leirner - Era me colocar em todos os lugares.

Independentemente de uma apreciação do que você estava fazendo.

Leirner - Nada. Ele nem via. Eu, por exemplo, tive uma exposição na galeria São Luís - considerada a melhor de São Paulo -, isso foi em 1959 ou 60, já com meus trabalhos feitos em meu ateliê. Nem a dona da São Luís, de quem eu não me lembro o nome, nem o... Quem escreveu o meu texto, foi o Ryzard Stanislawsky. 


\section{Como ele veio a escrever esse texto?}

Leirner - Ele era comissário da Polônia na Bienal. Meu pai era polonês.

E seu pai fez uma ponte para ele escrever um texto sobre sua exposição

Leirner - ...sem ver meu trabalho.

Leirner - Depois ele chegou a ser presidente da AIC - Associação Internacional de Crítica. Ele faleceu há uns três anos. Eu me encontrei com ele em Veneza em 1999. Mas ele vinha nos anos 60 ao Brasil. Porque a Bienal era por país, não era por conceito, curadoria. Não existia isso. Era como uma feira de arte por país. E como meu pai era polonês, ele tinha a função de tomar conta da Cortina de Ferro. Porque ele falava polonês, falava russo. Ele cuidava porque havia troca de prêmios. Eu assistia tudo. Era muito curioso. Então eles se reuniam, tinha o Mario Pedrosa, tinha, sei lá, o Sergio Milliet, todo esse pessoal que se reunia em casa. Então era negociação: "vamos dar o grande prêmio para os Estados Unidos", e meu pai negociava: “ô Mario, Estados Unidos levam o grande prêmio e nós levamos para Cortina de Ferro o prêmio de melhor escultor e melhor gravador. E para America Latina vai o de melhor desenhista". E assim eles compunham a premiação, ela era composta por negociação política.

O escritor austríaco Thomas Bernhard escreveu um livro em que relata como foi ganhar cada um dos prêmios de sua carreira. Na maioria dos casos, ele caracteriza como uma experiência negativa - a não ser pela parte em dinheiro -, algumas vezes também porque ele sabia do júri. Você ganhou vários prêmios, não?

Leirner - Pois é, depois vem a questão dos prêmios. Eu comecei a mandar meus trabalhos para os salões. Porque naquela época o artista tinha um percurso a ser cumprido. Você começava com o salão paulista, nacional, salão carioca, salão de Belo Horizonte... Bienal, esses eram seus degraus. E cada salão de que participava, recebia um prêmio.

\section{E como você se sentia?}

Leirner - Eu ficava muito contente. Porque eu não tinha consciência de que estava sendo manipulado.

Mas em 1967, quando você questionou o júri pelo aceite de seu próprio trabalho no Salão de Brasília foi diferente. 
Leirner - Bom, depois que meu pai faleceu, em 1962 - ele morreu cedo - eu continuei a trabalhar - junto do Geraldo de Barros e do Wesley [Duke Lee]; a Nova Objetividade, aquela exposição na FAAP que teve... e eu comecei a entrar politicamente - porque eu também tinha a visão, uma cultura de esquerda, política -, ai que eu comecei a perceber, e eu brinco e separo: Antes Papai AP e DP Depois Pai. Ficou muito clara essa demarcação. Só que depois eu segui com o meu trabalho.

Arte e jogo é uma aproximação que te interessou em diversos momentos. Como vê isso hoje com uma espécie de nivelamento do futebol com o marketing?

Nelson Leirner - Nos dias de hoje o marketing é a chave para tudo.

Mas você mesmo realizou obras e até um happening no Estádio do Morumbi envolvendo seu time, o Corinthians. Hoje, depois de ele ter sido campeão mundial de clubes, ainda se sente motivado a tentar traduzir seu sentimento de torcedor ou isso não mudou nada?

Leirner - Eu continuo envolvido com o futebol, com a política. Só que hoje, com a idade, os nervos estão mais à flor da pele. Eu sofro mais. Eu ia muito ao estádio.

E por que você sofre mais?

Leirner - Porque, na minha idade, os nervos estão muito mais aflorados, porra. Isso é normal.

E por falar nisso: como é ou foi a sua relação com as drogas?

Leirner - Só nos anos 60, na época da Rex, maconha, LSD.

\section{E foi importante?}

Leirner - É difícil você dizer se foi importante ou não porque tudo faz parte. Se você me perguntar onde é que foi importante, se você virou para cá ou prá lá... Não é o caso porque as pessoas têm que compreender que os pontos, coisas que acontecem, viram você para esquerda, viram você para a direita, até o fato de você conhecer e começar a namorar uma moça, todos os fatos que eu possa te dizer, até mesmo fora da arte, são importantes para o artista. Um porre é importante.

Sua proposta de fazer "orte" ou mesmo "arte" no lugar de ARTE tem a ver 
com uma inclinação por "obscurecer" ou "neutralizar" a forma e aderir ao conteúdo? De outro modo, você chega a ter algum desprezo pela convicção de que as artes plásticas ainda seriam algo a ser empreendido através de determinadas conquistas no campo do que é especificamente visual?

Leirner - É uma pergunta para ser respondida no divã de um psicanalista, pois tem a ver com problemas de autoestima, aura, ego... presentes no dia a dia vivencial.

\section{Você foi psicanalisado?}

Leirner - 30 anos. Eu e o Geraldo.

Mas parece que o Geraldo de Barros ficou mais envolvido.

Leirner - Ficou.

E os sonhos?

Leirner - O sonho não. Nunca liguei pro sonho. Nunca tentei interpretar os sonhos. Mas o meu dia-a-dia, sim. Uma bebedeira te leva, de repente a... Você puxa um fumo, você ouve uma música...

O Roberto Carlos, por exemplo.

Leirner - O Roberto Carlos foi a época. [referência à instalação Adoração (Altar de Roberto Carlos), de 1966]

Escutava a música dele?

Leirner - Não. Roberto Carlos era um mito, a adoração que havia, aquela coisa popular.

Você relacionava ele ao Catolicismo ou estava disponível assim como um Elvis Presley para o Warhol?

Leirner - Podia usar o Elvis, os Beatles, mas quis usar o Roberto Carlos porque ele era do nosso meio.

Existe uma diferença considerável entre o pop brasileiro e norte-americano?

Leirner - Total, pois vivíamos culturas diferentes especialmente quando nos 
referíamos à política. O consumismo presente no pop americano foi trocado pela nossa relação com a ditadura. No hemisfério norte não havia na época, nas artes, um conflito visual entre a esquerda e a direita. A esquerda americana era uma ameaça à chamada democracia, enquanto a nossa foi de encontro a uma ameaça antidemocrática.

\section{Como foi sua vivencia nos Estados Unidos, nos anos 1940/50?}

Leirner - Minha vivência nos Estados Unidos foi exatamente como eu gostaria que fosse. Sem responsabilidades, uma iniciação a como usufruir do "dolce far niente". Depois paguei pelos meus pecados.

\section{E acredita que seu trabalho teria tido um outro percurso se você não fosse brasileiro?}

Leirner - Claro. Porque eu uso muitas coisas, por exemplo, aqueles santos populares.

Mas tem também o Mickey Mouse com a Nossa Senhora. A cultura americana é algo presente na sua biografia e no seu trabalho, não?

Leirner - Sempre como uma crítica aos Estados Unidos, desde os anos 60, 70, assim.

Você teve uma experiência prolongada lá.

Leirner - Prolongada, boa, satisfatória. Eu critico os Estados Unidos politicamente. Eu vou para Nova York todo o ano. Adoro a cidade. Mas critico os Estados Unidos no meu trabalho por uma questão de poderio, político. Eles dominam sorrateiramente o mundo.

\section{Bem como o sistema das artes?}

Leirner - Eu acho que sim. Hoje em dia, pelo que eu ouço falar - eu não frequento essas feiras, sabe? -, não vou para São Paulo para ver uma SP-Arte. Não.

\section{Isso não te interessa?}

Leirner - A galeria que se cuide. Agora, se você pega hoje os Estados Unidos, a Alemanha ou Inglaterra, o que é que eles vêm fazer aqui? Eles atrapalharam, eles estão entrando firme no mercado brasileiro com trabalhos de lá - isso eu ouvi falar depois. Eles estão tirando uma grande porcentagem das vendas dos brasileiros e 
entrando com obras caras porque tem muita gente rica aqui.

\section{Mais um processo de exportação deles do que de importação.}

Leirner - Eles estão exportando muito mais. Eles estão entrando, do mesmo jeito que eles sempre entraram... E é esse entrar sorrateiro que me põe sempre em alerta. Por exemplo, o que eles faziam nos anos 70 gerou um trabalho que chamei de Projeto Care. Um projeto com latas. Era o seguinte: "care", em inglês, que aqui se tornou "care". O americano vinha trazer como ajuda, no Norte, Nordeste, óleo, óleo de cozinha, sal, manteiga, vinha tudo em latas e traziam como ajuda... Care, ajuda aos sub-desenvolvidos. E instalavam uma base em Natal. E para compensar essa infiltração eles davam essa ajuda, toda ela baseada em comida. O nordestino que era muito criativo, pegava as latas e transformava em objetos de uso: pratos, lamparinas, brinquedo para as crianças. Então todos aqueles objetos que você via feitos em lata, da época, eram frutos da ajuda americana. É muito curioso esse processo da ajuda ser transformada pelo pobre em objetos de uso - não só o que estava dentro -, mas também o lixo. O lixo era transformado com a criatividade que o brasileiro tem em objetos maravilhosos. A Lina Bo Bardi tinha uma coleção incrível disso.

\section{E o seu projeto?}

Leirner - O meu projeto era com latas de Coca-Cola, a Pepsi invade, posterior, mas visando esse mesmo processo. A Coca-Cola invade, as multinacionais invadem...

\section{Você transformava em trabalhos?}

Leirner - Críticos: carrinhos de supermercado cheios de latas. Isso vem de uma consciência política.

\section{De 1970 para cá, nessas transformações de uma coisa em outra, você viu muitos Leirners, Nelsons Leirners serem multiplicados com objetivos estético ou comercial?}

Leirner - Não vi muito. Vi muita gente assumir. Vi pessoas que me trouxeram inclusive Fontanas [Homenagem a Fontana], zíperes, em outras cores, feitos por artistas usando meu próprio trabalho. Isso eu vi.

\section{Você gostou?}

Leirner - Não... É igual ao trabalho que eu fiz há tanto tempo. Então há muita 
gente reproduzindo, não idênticos, mas com o mesmo mecanismo, sempre citando.

Era uma homenagem ao Lucio Fontana e agora seria uma homenagem a você.

Leirner - A mim. Essa citação costuma acontecer.

\section{E em termos de falsificações?}

Leirner - Não percebi ainda. Não fui. Mas o que ocorre muito é o seguinte: ainda o meu Homenagem a Fontana, dos anos 60. Na época, pessoas para quem eu dei um da série, que ficaram com esses trabalhos, não tinha valor. Tanto que era vendido por preço de custo, toda aquela coisa com o Geraldo, que a gente fazia. Os preços industrialmente. As pessoas não davam a mínima atenção a isso. Eles jogavam em um porão... Quando isso começou a adquirir um valor comercial, as pessoas se lembravam que tinham.

\section{Ainda mais porque não eram óleos sobre tela, mas coisas comuns.}

Leirner - Mas o estado do trabalho era absolutamente vergonhoso. E as pessoas pediam para eu restaurar, muitas pessoas. Só que não existe mais o mesmo material, você não encontra mais na mesma lonita, na mesma cor. Não dá para tingir, a mesma textura, não tem mais a mesma moldura de alumínio porque esse tipo de moldura não se fabrica mais... Afinal são 50 e tantos anos. Mas as pessoas, quando adquirem algo que não tem valor comercial, elas põem no lixo.

\section{Na sua família a figura do colecionador é muito presente. Como vê o colecionismo?}

Leirner - Hoje em dia existe aquele que realmente gosta de colecionar, o consumidor. Existe a pessoa que gosta de consumir.

\section{Mas a arte é passível de ser consumida, de fato?}

Leirner - É... Você já viu um colecionador de selo, atrás de selo? É igual a um colecionador de arte atrás de arte. E existem aqueles que têm a visão comercial.

\section{Mas o que o colecionador compra, a função do trabalho?}

Leirner - Ele compra o nome. A assinatura. Deixa eu te mostrar uma coisa (segue para a varanda e mostra um exemplar parcialmente destruído de seu trabalho Homenagem a Fontana). Esse é um original, de 1967. Olha o estado... O que 
aconteceu: ele é fruto do incêndio do MAM/RJ (em 1978).
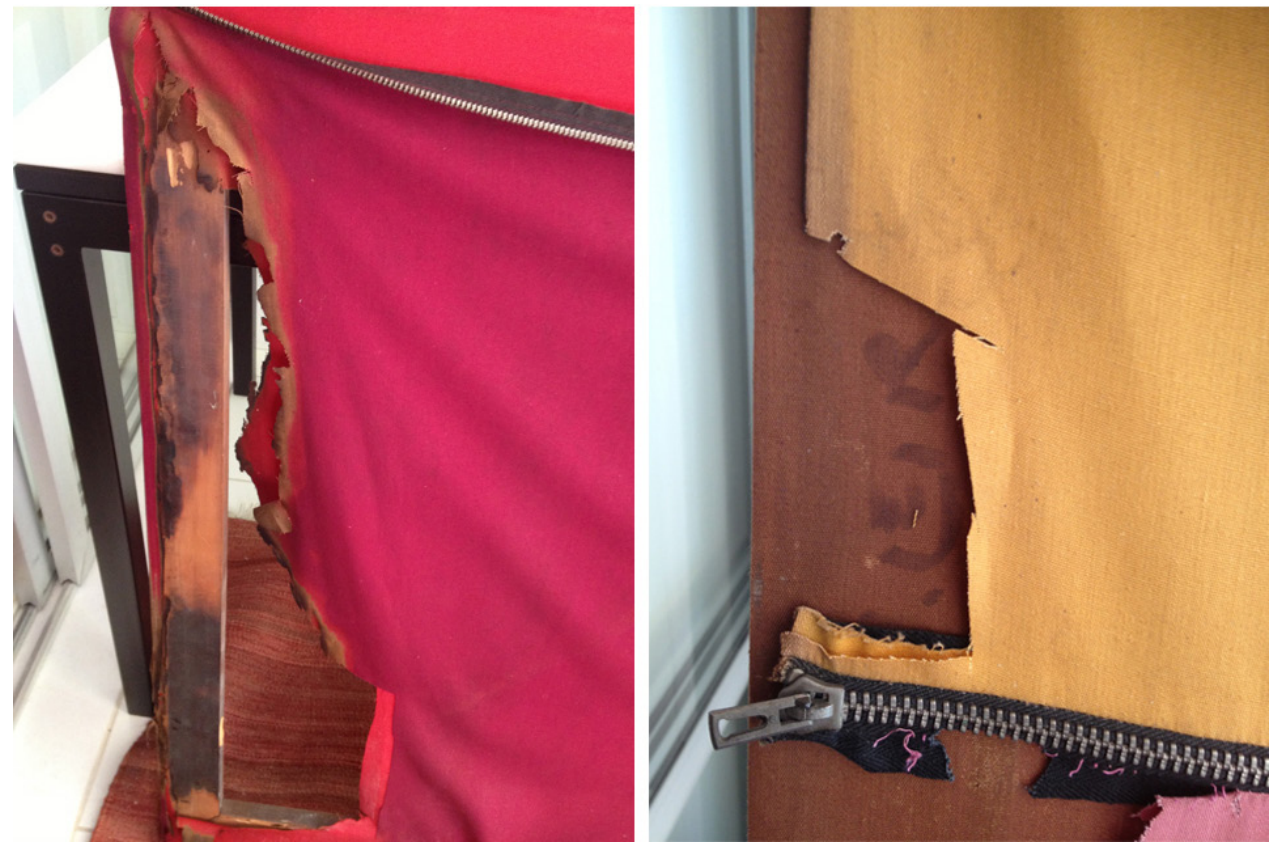

\section{Sobreviveu ao incêndio.}

Leirner - Ficou, desde o incêndio lá, no MAM. Num depósito. Quatro meses atrás, o Camillo [Luiz Camillo Osório] , depois que assumiu a diretoria, chegou para mim e disse: "Nelson, esse é um trabalho precioso, que está em vários museus, e é um trabalho que o público merece ver aqui. Não tem como restaurar?" E ele disse "vou expor o trabalho nesse estado, que aconteceu, e você vai, por favor, com o que você encontrar de mais próximo, me fazer um simulacro para eu mostrar pro público ver como é, para eles poderem ver, interferir, sem o valor do trabalho de 1967... Escrito mesmo, "simulacro", com a data de hoje.

\section{E naturalmente aceitou?}

Leirner - Claro que aceitei. Porque o Camillo é amigo e é o museu... Eu não consegui fazer ainda. Eu estou ainda procurando o material para fazer o mais próximo possível. Só para te dizer que de repente esse trabalho interessou ao museu ter, porque ele está na Tate, no Malba, porque esse é um múltiplo. Logo depois do incêndio esse trabalho não tinha valor para o pessoal do museu.

\section{E o marchand, o que você pensa sobre essa figura?}

Leirner - Olha, depende. Ou você tem uma confiança absoluta, sua, de dentro, e você aceita o que ele faz, ou, se você tem alguma coisa que se relaciona com a 
picaretagem do marchand, você tem que sair fora.

\section{$\mathrm{O}$ artista se relaciona com a picaretagem ou detecta ela?}

Leirner - Você detecta, você vê, você acaba sempre tendo uma pequena prova, aí você cai fora. Sai. Mesmo que você fique sem ninguém.

\section{E o que seria exatamente a picaretagem?}

Leirner - Picaretagem é o seguinte: dar desconto sobre o seu trabalho sem dar... E fica com o desconto no bolso. Usar seu trabalho para pagar outras coisas e não prestar contas contigo e você vai descobrir um ano depois que ele usou o seu trabalho para pagar o livro de um outro artista. Porque ele tem um monte de trabalhos seus e não dá para ficar todo o dia fazendo contas. Ele vende e não repassa a venda. O que você pegar, ele fala "...ah, esqueci”. Ele pede para cuidar de um setor de fotos. "Ah, vamos fazer; tiragem de quatro e tal. Deixa que eu cuido disso". Quando você vai ver, ele fez cinco..., uma ele guardou na casa dele.

\section{Isso te aconteceu muitas vezes?}

Leirner - Não porque eu tive poucas galerias. Mas aconteceu, com duas.

\section{Walter Benjamin escreveu um breve texto chamado O Caráter Destrutivo no qual ele diz o seguinte:}

\section{"O caráter destrutivo é o inimigo do homem-estojo. O homem-estojo busca} sua comodidade, e a caixa é sua essência. $O$ interior da caixa é a marca, forrada de veludo, que ele imprimiu no mundo. $O$ caráter destrutivo elimina até mesmo os vestígios da destruição.”

\section{O que lhe parece?}

Leirner - Eu falei sobre isso com alguém, faz pouco tempo. Você pode falar sobre destruição na arte e você pode falar em auto-destruição. E dentro da arte eu estava citando o Kurt Schwitters, com o Merzbau que furava o teto, não cabia... Então ele destrói para ser destruída a destruição [o trabalho foi destruído, em 1943, em um bombardeio dos Aliados]. E isso me lembrou também um filme maravilhoso do Alec Guinness [The Horse's Mouth (1958)]. Ele trabalhava num barco, era pintor. Ele pintava. Só que os quadros tinham certa dimensão e cabiam no barco dele. Mais do que isso ele não podia. Daí ele pega o barco dele e vai atrás de um transatlântico e fica junto e começa a pintar o casco do transatlântico que vai andando devagar. Então o espaço físico acaba. 
Vê uma diferença significativa entre Rio e São Paulo, em relação a isso?

Leirner - O espaço aqui é um espaço que eu não uso. O Rio é muito mais espaçoso, você tem um Jardim Botânico, em que eu posso andar.

\section{Anda por lá?}

Leirner - Não. Eu sou urbano. Eu gosto de cidade... Você tem as praias.

\section{Você vai à praia?}

Leirner - Acho que eu nunca fui à praia no Rio. Eu venho de outra... Eu saio, eu ando..., eu saio cada vez menos.

\section{E você deu aulas por muito tempo na FAAP e depois no Parque Lage. Foi diferente?}

Leirner - Total. O Parque Lage era um curso livre. E na FAAP, por mais livre que a arte seja, você tinha na mão a nota. Uma caderneta e a nota. Então, de certa forma, $\mathrm{o}$ aluno pode ser manipulado. Mesmo que eu brincasse muito com isso, a nota é um meio de você, de repente, forçar algo que acha que deva ser forçado.

\section{Como brincava com isso?}

Leirner - Às vezes eu perguntava para uma classe: quem quer tirar nota cinco e não frequentar o curso? Então levantavam dois ou três... Depois eu perguntava: e quem quer tirar nota sete e não frequentar o curso? Depois no baralho: vocês têm de um a quatro para serem reprovados. Olha quantas chances, 60 por cento de ser aprovado, até dez... Quem quer tirar? Aí o cara tirava três. Reprovado. Então você não volta atrás.

\section{E como é que a direção da escola lidava com isso?}

Leirner - Eram os anos 80, alunos maravilhosos, o Zerbini, o próprio Leonilson, a Dora [Dora Longo Bahia], o Iran [Iran do Espírito Santo].

\section{Lembra de algum dos reprovados?}

Leirner - Com os que foram eu nem sei o que aconteceu.

Quer dizer então que a atividade de professor foi boa para você. 
Leirner - Boa, muito satisfatória. Agora, ela teve uma coisa que para mim, vivencialmente, foi negativa: eu não consegui criar vínculos com pessoas da minha idade. Todo meu vínculo foi sempre com jovem. E eu não tenho amigos, vamos dizer, mais velhos.

\section{E do pessoal da Rex, Carlos Fajardo, José Resende?}

Leirner - Primeiro que eles estão em São Paulo. Segundo que são muito mais jovens. Os outros dois que eram da minha idade faleceram: o Geraldo e o Wesley. Minha geração está indo embora.

\section{E você se dava bem com o Wesley?}

Leirner - Cada um respeitando as diferenças.

\section{Mas tinha em comum uma inclinação para a sátira?}

Leirner - Tinha, tinha muita coisa em comum. Agora, ninguém criticava o outro por suas posições políticas. O Wesley era de extrema direita e nós de esquerda - eu e o Geraldo.

\section{E você aprecia o trabalho do Wesley?}

Leirner - Eu gosto da organização do Wesley. Porque você sempre se vê pelo seu oposto. E o trabalho dele tem um ritmo de organização. Conhecendo pelo seu fluxo total, não individual, eu acho que há essa coerência dele e esse acreditar. Porque ele acreditava no trabalho e a maneira como ele cuidava do trabalho é algo em que nós fomos totalmente opostos, principalmente eu.

\section{O Helio Oiticica também teve uma trajetória paralela à sua, não? Você chegou a dialogar com ele?}

Leirner - Eu encontrei com ele só naquele movimento das bandeiras na praça que fizemos no Rio, em que ele lançou aquela bandeira "Seja Marginal, Seja Herói”. Foi a bandeira que ele fez para nós.

\section{Um evento organizado por você?}

Leirner - Por mim e pelo Flávio Motta no Rio. Quando nós fomos, em São Paulo, colocados como camelôs e todas as bandeiras foram apreendidas e jogadas num depósito - e tivemos que pagar uma multa -, resolvemos organizar uma festa no 
Rio. Então foi o pessoal do teatro, foi o Helio Oiticica, o Vergara, aí chamamos o Marcello Nitsche de São Paulo, o Claudio Tozzi, a Carmela [Gross], o Gerchman, o Antonio Dias. Cada um fez uma bandeira, por um domingo. A Banda de Ipanema, o Oiticica trouxe os passista da Mangueira. Para mostrar que no Rio, as coisas, mesmo políticas - dentro da arte e sociedade - eram mais festivas, tinham outro caráter. (Pausa) Eu não conheço muito bem a história da ditadura no Rio. Eu conheço bem a de São Paulo - amigos presos, amigos mortos.

Você sempre teve um trabalho combativo e...

Leirner - ...passava. Porque a arte, muitas vezes, tem um nível que não atinge. Você consegue burlar.

E o que sente a respeito de alguém que reivindica, enfatiza que seu trabalho foi perseguido?

Leirner - Eu só tive uma perseguição forte. Quando fui condecorar o porco na TV Cultura. Eu cheguei lá com um discurso de general. O programa saiu do ar.

Uma paródia de figuras do regime, na performance?

Leirner - Tinha porque era tirar o porco do engradado e dar medalhas por serviços prestados por coronéis em Brasília.

Houve outro caso envolvendo censura ao seu trabalho na década de 1990.

Leirner - Censura relacionada à pornografia eu tive no caso envolvendo Anne Guedes (fotógrafa de quem Leirner se apropriou de fotos de domínio público de bebês, sobre as quais interveio graficamente), os trabalhos retirados do MAM do Rio, em 1998. Houve um processo por pedofilia e um processo por atentado à moral.

\section{E existe pornografia na arte?}

Leirner - Não existe. Na arte, não. Ao mesmo tempo em que você publica, como eu publiquei numa revista espanhola, toda uma série erótica, aqui sou processado por uma socialite e pego um processo de dois anos.

\section{E você ganhou o processo?}

Leirner - Ganhei. Foi arquivado. 
Já ouvi você dizer que gosta do artista russo Ilya Kabakov. $O$ trabalho dele tem um lado político, mas também um lirismo. Há essa inclinação e sensibilidade no seu próprio trabalho?

Leirner - Gosto muito do trabalho do Kabakov, por sua ocupação precisa dos espaços, colocando o espectador em um constante labirinto o que nos põe como artistas uma questão importante: precisa esse labirinto, ser árido? Ele pode ser construído com elementos líricos, ou enganar o expectador de tal forma que ele se sinta bem esquecendo momentaneamente a angústia que vira quando se encontrar com a dificuldade de sair dele. O humor no meu trabalho é uma armadilha para dificultar encontrar a saída.

Em seu trabalho que partia da expressão de Duchamp, "burro como um pintor", você convida vários profissionais, artistas e não artistas para fazer uma série com motivos florais, com caneta bic.

Leirner - Ali foi outra coisa. Eu chamei de Projeto Aula. Eu peguei alunos meus da FAAP e para outras pessoas eu ditei regras. Porque eu peguei comerciários, dona de casa, pessoas que não tinham nada que ver com a arte. E eu não estava ligando para o processo da arte, mas para as regras que eu impunha. Eu dei flores, o tamanho do papel, o desenho da flor, eu fiz várias flores, para cada um eu dei uma flor, que eu tirei de um livro de uma americana, e você só podia usar a caneta bic.

\section{Com algumas cores?}

Leirner - Quatro cores: verde, vermelho, azul e preto. À vontade, e você tinha que preencher com essa caneta bic todo o papel e preencher as flores. Então a pessoa recebe a folha de $170 \mathrm{~cm}$, já com a flor - uma flor grande, sempre uma flor...-, uma com folha, outra sem folha... Era uma cópia. Como se você fizesse um xerox de uma flor e eles tinham, cada um, que preencher ou fazer a flor do seu modo. E quando você pega o resultado de 24 pessoas que fizeram e você colocou uma perto da outra e você misturou, não dava para saber quem era quem e não dava para saber quem estava ligado à arte e quem não estava ligado à arte.

\section{E você também não participa desse processo.}

Leirner - Não, eu deixei os outros fazerem. Como uma aula. Agora, se você pegasse o trabalho da dona de casa e o da Dora, elas sabiam o que tinham feito, mas se você perguntar para uma terceira pessoa qual foi feito por um comerciário ou uma aluna de arte. Na hora que eu dito a regra, não tinha assinatura. Então todos os 24 trabalhos expostos tinham uma coerência total. Quando você dita uma regra, você consegue através da regra, eliminar a criação. Eles estavam 
proibidos de criar. Eles tinham que seguir. Então isso dava um sentido de mostrar a eles que na arte não adianta você seguir uma regra, um caminho, coisas já dadas.

Uma das pessoas que participou dessa exposição, a Monica Nador, não me parece ter seguido a regra exatamente, mas talvez tenha tomado o exemplo e incorporado essa ideia de que poderia não ser ela, artista, a fazer o trabalho, mas propor algo indireto. Ela começou - justamente com um trabalho em sua homenagem no MAM de São Paulo - uma série de pinturas em paredes com a participação de outras pessoas, o princípio de uma "autoria compartilhada". Nesse trabalho que ela realiza no Jardim Miriam, você vê uma relação com o Projeto Aula?

Leirner - Ela podia sublocar meu trabalho. Você pode pegar esse trabalho e subloca ele para sua empregada. E o resultado ia ser o mesmo, e você apresenta com o seu nome. Depois, quando ela largou, deixou de estar no circuito comercial, ela começou a fazer uma arte pública.

Não há uma ligação com o que você "ensinou"?

Leirner - Na cabeça dela, pode ter. O que cada um ligou a mim durante os 28 anos de FAAP é absolutamente da cabeça da pessoa.

Ela foi para um campo social e fala em encontrar uma "beleza pura". Como vê a beleza no seu trabalho, ela pode superar a ideia de arte, no sentido de que você chegue a algo que não quer ser Arte, mas pode, ainda assim, ser belo?

Nelson Leirner - Falar de "beleza pura" é perigoso pois muitas conotações podem ser dadas, tendo como exemplo as atrocidades de Hitler. A noção do belo varia com as épocas e culturas, logo usando um ditado popular, "tem gosto para tudo".

No trabalho da Nador, essa expressão vem da canção do Caetano Veloso, na qual rima com "a carne escura". Quer dizer o contrário de uma "raça pura". Seria, acredito, a procura por uma beleza que está sendo negligenciada, mais espontânea, de caráter popular.

Leirner - Não sei o que seria "beleza pura". Para mim eu coloco a beleza pura, por exemplo, no que está acontecendo com a arte hoje. Toda arte hoje, tanto do jovem, quanto a nossa, se tornou "beleza pura".

E você vê isso com otimismo, com ceticismo?

Leirner - É uma constatação só. Você constata. Hoje tudo é beleza pura. 
E como ela se manifesta, por exemplo, na diferença entre seu porco empalhado e os trabalhos do Demien Hirst que fez, bem depois, um...

Leirner - Tubarão... Mas ele não conhecia meu porco e eu não conhecia as ideias do Demien Hirst, apesar de ele ser muito mais jovem.

\section{Mas você vê beleza no trabalho dele?}

Leirner - Tudo é beleza. O processo é beleza pura, não é o trabalho em si. Você não olha esteticamente o trabalho, você olha o processo de hoje. O processo hoje em dia eu chamaria, e é até uma boa ideia, eu chamaria de beleza pura. O que você fizer, o que você faz, porque ela já tem um rumo que é esse rumo da beleza mesmo.

\section{E você vê alguma motivação nisso? Teria a ver com o mercado?}

Leirner - Ah, tem. Tem a ver com o jovem, tem a ver com arrogância. Hoje eu acho, por exemplo, o jovem, a curadoria jovem, acho esse pessoal extremamente arrogante. Eles são de uma arrogância que não passava pelas nossas cabeças. Nós éramos artistas para quem a arte fazia parte do nosso cotidiano. Não tínhamos ninguém, sabe? A gente conversava, falava, mas não havia... Hoje você sente no artista e na arte que eles são extremamente arrogantes.

\section{E no caso do curador, que não é um produtor de arte, exatamente?}

Leirner - Mais arrogante ainda. Eles são de uma arrogância, de um ego, de algo que você foge, né? Você foge disso. E isso é uma questão de uma sociedade jovem que evoluiu para esse lado.

\section{O humor foi importante para você?}

Leirner - Eu sou muito cínico. Eu era muito cínico... - até isso você vai perdendo. Mas é uma coisa que eu gosto. Mas não o cínico no sentido do dicionário. É aquele cinismo com humor. Um pouco Steinberg [Saul Steinberg], de um cinismo total. O trabalho dele, quando ele faz as máscaras, ele pega a sociedade. Ele alfineta. Então eu adoro perceber no outro, pessoas que você conhece, você fica quieto, você percebe e de repente você entra com uma, sabe? E cai aquela risada, o outro fica meio... Isso eu tinha muito. Agora como eu saio menos eu tenho... menos chance, em jantares... Mas eu tenho muito dessa picardia.

E você acha que arte atual - você falou aqui de uma aridez de certas instalações 
- perdeu a graça?

Leirner - Perdeu. A arte está chatérrima. A arte jovem está chata, chata porque eles se sentem artistas. A merda é essa. E artista é uma coisa que não se sente ser. Você vê uma exposição hoje e percebe que ele quer se sentir dentro de um ego que diz: "eu sou artista." Quase como ele tivesse que andar carregando aquele tubo de papel, um quadro debaixo do braço e um cavalete. Você vai ver uma exposição e é de uma chatice..., você percebe um ego tão grande, uma vontade tão grande de que o trabalho dele seja reconhecido como arte e que ele próprio quer se sentir o artista.

\section{Estaria relacionado ao poder de ser artista hoje?}

Leirner - Que poder?

Estou pensando, por alto, em algo como Inhotim: o artista ter lá um pavilhão permanente, com centenas ou até milhares de metros quadrados só para seu trabalho.

Leirner - E? Ele vai carregar isso como? Inhotim é, você me desculpe, um antro. Pode até ter coisas boas, mas é um antro de jovens curadores que através de um espaço de arte, de novo, querem impor o seu poder e serem respeitados por serem... curadores de Inhotim. Então o que é o que eles querem: ter todo mundo atrás. E são todos jovens.

Está me parecendo que você tinha uma boa relação com os jovens e agora...

Leirner - Mas mudou. As coisas mudaram. A geração 80 era bacana. Parou ai. O que eu digo do curador jovem é que eles precisam do poder para serem bajulados. Então fica todo mundo bajulando o curador jovem.

Quais você diria que foram as contribuições do público para sua trajetória? Em que nível ele participou?

Leirner - Pena que não dá para responder a essa mesma pergunta em diversos momentos de minha carreira. Digamos, no mínimo a cada dez anos. Hoje, aos 81 anos, eu diria que em nenhum.

Rio de Janeiro, 22.04.2013 